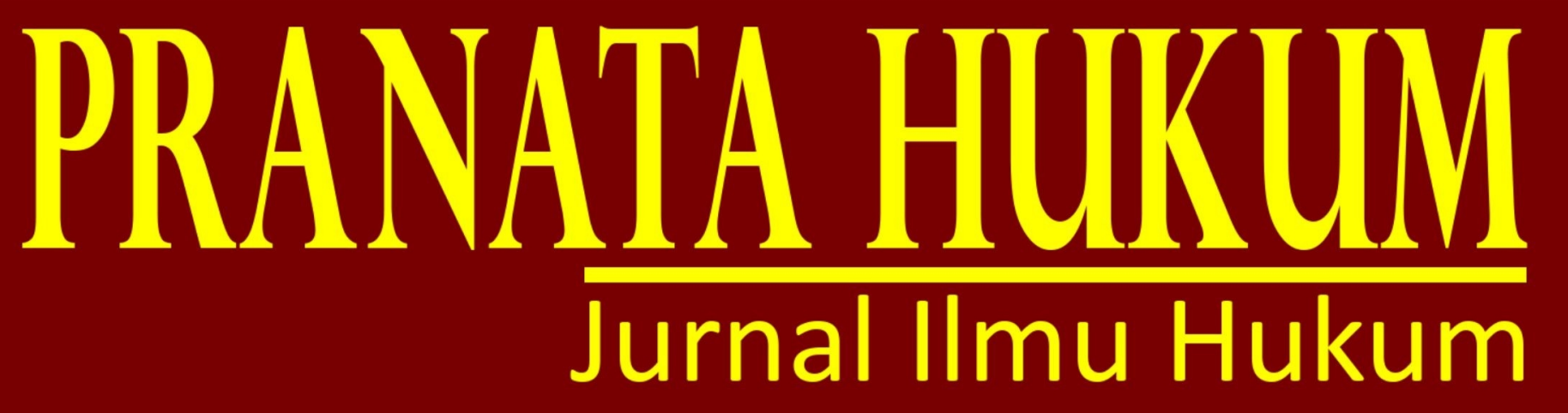

e-ISSN 2685-3213 | p-ISSN 1907-560X

EFEKTIVITAS ASEAN CONVENTION ON COUNTER TERRORISM DI DALAM MEMBERANTAS PEMBAJAKAN DI WILAYAH PERAIRAN ASIA TENGGARA

Rafi Darajati, Muhammad Syafei

PERLINDUNGAN HUKUM PENGGUNA JALAN DARI ANGKUTAN UMUM ONLINE PADA PENGGUNAAN TELEPON SAAT MENGEMUDI KENDARAAN

Rissa Afni Martinouva

ANALISIS PERTANGGUNGJAWABAN PELAKU TINDAK PIDANA MELAKUKAN PENEBANGAN POHON DALAM KAWASAN HUTAN TANPA IJIN YANG BERWENANG

Sukoco SP, Erlina B , Eddy S Wirabhumi

PERLINDUNGAN HUKUM PASIEN PADA BIDAN PRAKTIK MANDIRI DI INDONESIA PASCA DIKELUARKANNYA UNDANG-UNDANG NOMOR 4 TAHUN 2019 TENTANG KEBIDANAN Aditia Arief Firmanto

FUNGSI PENGAWASAN PERADILAN TATA USAHA NEGARA TERHADAP PERBUATAN PEMERINTAH PASCA UNDANG-UNDANG NOMOR 30 TAHUN 2014 TENTANG ADMINISTRASI PEMERINTAHAN Muhammad Rusjana

PELAKSANAAN PENGADAAN BARANG/JASA PEMERINTAH DITINJAU DARI PERPRES NOMOR 16 TAHUN 2018 TENTANG PENGADAAN BARANG/JASA PEMERINTAH DI KANTOR PERTANAHAN KOTA BANDAR LAMPUNG Aryana Wisastra, Baharudin, Indah Satria

KEWAJIBAN TANGGUNG JAWAB SOSIAL PERUSAHAAN (CORPORATE SOCIAL RESPONSIBILITY) DI INDONESIA: ANTARA LEGAL OBLIGATION ATAU MORAL OBLIGATION

Dani Amran Hakim, Dania Hellin Amrina

IMPLEMENTASI PERATURAN MENTERI AGRARIA DAN TATA RUANG/KEPALA BADAN PERTANAHAN NASIONAL NOMOR 13 TAHUN 2017 TENTANG TATA CARA BLOKIR DAN SITA PADA KANTOR PERTANAHAN KOTA BANDAR LAMPUNG

Sholin Erbin M Rajagukguk, Lintje Anna Marpaung, Herlina Ratna Sumbawa Ningrum

PEMBERIAN PATEN OBAT-OBATAN DAN PEMENUHAN HAK ASASI MANUSIA TERHADAP KESEHATAN DI INDONESIA

Chandra Muliawan

\begin{tabular}{c|c|c|c|c|}
\hline $\begin{array}{c}\text { PRANATA } \\
\text { HUKUM }\end{array}$ & $\begin{array}{c}\text { Volume } \\
14\end{array}$ & $\begin{array}{c}\text { Nomor } \\
\mathbf{2}\end{array}$ & $\begin{array}{c}\text { Halaman } \\
96-222\end{array}$ & $\begin{array}{l}\text { Bandar } \\
\text { Lampung } \\
\text { Juli 2019 }\end{array}$ \\
\hline
\end{tabular}




\section{PRANATA HUKUM}

Jurnal Ilmu Hukum

Magister Hukum

Universitas Bandar Lampung

Terbit Pertama Kali, Juli 2006

Terbit Dua Kali Setahun, Setiap Januari dan Juli

PENANGGUNG JAWAB

Rektor Universitas Bandar Lampung

KETUA PENYUNTING

Prof. Dr. Lintje Anna Marpaung, S.H., M.H

WAKIL KETUA PENYUNTING

Dr. Bambang Hartono, S.H., M.Hum

PENYUNTING PELAKSANA

Dr. Tami Rusli, S.H., M.Hum

Dr. Erlina B, S.H., M.H

Dr. Zainab Ompu Jainah, S.H., M.H

Indah Satria, S.H., M.H

Yulia Hesti, S.H., MH

\section{PENYUNTING AHLI (MITRA BESTARI)}

Prof. Dr. I Gusti Ayu Ketut Rachmi Handayani, S.H., M.M (Universitas Sebelas Maret) Prof. Dr. I Gede A.B Wiranata, S.H., M.H (Universitas Lampung)

Dr. Nurhadiantomo, S.H., M.Hum (Universitas Muhammdiyah Surakarta)

Dr. Erina Pane, S.H., M.H (UIN Lampung)

Alamat:

Kampus B Universitas Bandar Lampung

Jl. Z.A Pagar Alam No.89 Labuhan Ratu, Bandar Lampung 35142

Telp: 0721-789825 Fax: 0721-770261

Email: jurnal.mh@ubl.ac.id

Jurnal PRANATA HUKUM dimaksudkan sebagai media komunikasi ,edukasi dan informasi ilmiah bidang ilmu hukum. Sajian dan kemasan diupayakan komunikatif melalui bahasa ilmiah.

Redaksi mengundang semua elemen masyarakat ,baik civitas akademika, praktisi , lembaga masyarakat ,maupun perorangan yang berminat terhadap bidang hukum untuk berpartisipasi mengembangkan gagasan, wawasan, dan pengetahuan melalui tulisan untuk dimuat dalam jurnal ini. Melalui PRANATA HUKUM diharapkan terjadi proses pengembangan bidang hukum sebagai bagian penting dari rangkaian panjang proses memajukan masyarakat bangsa 


\title{
IMPLEMENTASI PERATURAN MENTERI AGRARIA DAN TATA RUANG/KEPALA BADAN PERTANAHAN NASIONAL NOMOR 13 TAHUN 2017 TENTANG TATA CARA BLOKIR DAN SITA PADA KANTOR PERTANAHAN KOTA BANDAR LAMPUNG
}

\author{
Sholin Erbin Mart Rajagukguk, ${ }^{1}$ Lintje Anna Marpaung, ${ }^{2}$ Herlina Ratna \\ Sumbawa Ningrum. ${ }^{3}$
}

\begin{abstract}
According to regulation of the Minister of Agrarian and the spatial/Head of national Land Agency No. 13 of 2017 concerning the block and Confiscation procedure, the registration is the administrative action of the head of the land office or the appointed official to establish State of the status quo (freezing) on land rights that are provisional to the Act and legal events of the land, while the recording of the seized is the administrative action of the head of the land office or the appointed officer to Record any seized from judicial institutions, investigators or other competent institutions. This writing problem is how the implementation of regulation of the Minister of Agrarian and Spatial/Head of national Land Agency No. 13 of 2017 about procedure block and Confiscation at the Land office of Bandar Lampung. The implementation of the regulation of the Minister of Agrarian and Spatial/Head of national Land Agency number 13 year 2017 about the procedure of block and Confiscation at the Land Office of Bandar Lampung is not currently implemented in the maximum Because it is still not in sync between regulation of the Minister of Agrarian and the spatial/Head of national Land Agency No. 13 of 2017 about procedures for blocking and Confiscation with the application for land services efforts.
\end{abstract}

Keywords: implementation, block logging, Confiscation.

\section{PENDAHULUAN}

Tanah merupakan karunia Tuhan Yang Maha Kuasa untuk kesejahteraan bangsa Indonesia, sehingga hubungan Bangsa Indonesia dengan tanah bersifat abadi. Hubungan Bangsa Indonesia dengan tanah yang merupakan kekayaan nasional sangat menentukan kesejahteraan, kemakmuran, keadilan, keberlanjutan dan harmoni bagi bangsa dan Negara Indonesia. Bagi bangsa Indonesia, hubungan manusia/masyarakat dengan tanah merupakan hal yang sangat mendasar dan asasi. Jika hubungan ini tidak

\footnotetext{
${ }^{1}$ Mahasiswa Magister Hukum Universitas Bandar Lampung, viva.parna@gmail.com

2 Dosen Magister Hukum Universitas Bandar Lampung, lintje@ubl.ac.id

3 Dosen Magister Hukum Universitas Bandar Lampung, herlina@ubl.ac.id
} 
tersusun dengan baik, akan lahir kemiskinan bagi sebagian terbesar rakyat Indonesia, ketidakadilan, peluruhan serta sengketa dan konflik yang berkepanjangan yang bisa bersifat struktural. Hubungan yang mendasar dan asasi tersebut dijamin dan dilindungi keberadaannya oleh Pasal 27 ayat (2), Pasal 28A, Pasal 28D ayat (1), Pasal 28G ayat (1), Pasal 28H, Pasal 28I, Pasal 33 ayat (3) Undang Undang Dasar Negara Republik Indonesia Tahun 1945.

Sejalan dengan UUD Tahun 1945 yang menunjukkan suatu perjalanan kebangsaan dan kenegaraan Indonesia, sebagaimana yang tertuang dalam alinia ke-4 Pembukaan UUD Tahun 1945, bahwa Pemerintah Negara Republik Indonesia ini dibentuk untuk melindungi segenap bangsa Indonesia dan seluruh tumpah darah Indonesia, memajukan kesejahteraan umum, mencerdaskan kehidupan bangsa, dan ikut melaksanakan ketertiban dunia yang berdasarkan kemerdekaan, perdamaian abadi dan keadilan sosial, bahwa ujung dari cita-cita Negara adalah mewujudkan keadilan sosial bagi seluruh rakyat Indonesia. Untuk mewujudkan kebijakan negara mengenai penataan dan pengelolaan sumber daya alam, sebagaimana yang dimuat dalam Pasal 33 ayat

(3) Undang-Undang Dasar Negara Republik Indonesia Tahun 1945 yang menyatakan : "Bumi dan air dan kekayaan alam yang terkandung didalamnya dikuasai oleh negara dan dipergunakan untuk sebesar-besar kemakmuran rakyat", negara menetapkan garis kebijakan nasional dibidang pertanahan yang merupakan salah satu unsur penting dari sekian banyaknya potensi Sumber Daya Alam yang ada.Oleh karena itulah pada tanggal 24 September 1960 disahkan Undang-Undang Nomor 5 Tahun 1960 Tentang Peraturan Dasar Pokok Agraria.

Timbulnya sengketa atas tanah bermula dari adanya pengaduan pihak (orang/Badan Hukum) yang berisi keberatan-keberatan dan tuntutan hak atas tanah baik terhadap status tanah,prioritas maupun kepemilikannya. Sengketa yang terjadi tidak hanya atas tanah yang belum terdaftar tetapi juga atas tanah yang terdaftar. Pihak-pihak yang merasa berhak dan berkepentingan atas suatu bidang tanah mengajukan gugatan ke pengadilan, yang mengakibatkan terjadinya pemblokiran hak atas tanah.

Kementerian Agraria dan Tata Ruang/Badan Pertanahan Nasional telah mengeluarkan Peraturan Menteri Agraria dan Tata Ruang/Kepala Badan Pertanahan Nasional Nomor 13 Tahun 2017 tentang Tata Cara Blokir dan Sita, disebutkan bahwa pencatatan blokir adalah tindakan administrasi Kepala Kantor Pertanahan atau pejabat yang ditunjuk untuk menetapkan keadaan status quo (pembekuan) pada hak atas tanah yang bersifat sementara terhadap perbuatan hukum dan peristiwa hukum atas tanah tersebut, sedangkan pencatatan sita adalahtindakan administrasi Kepala Kantor Pertanahan atau pejabat yang ditunjuk untuk mencatat adanya sita dari lembaga peradilan, 
penyidik atau instansi yang berwenang lainnya. Pemblokiran dapat terjadi karena adanya hubungan kepentingan antara pemblokir dan pemilik tanah ataupun kepentingan pemilik tanah itu sendiri. Misalnya adanya hubungan hutang-piutang yang bermasalah, wanprestasi, sertipikat hilang, pembagian waris yang tidak adil, pemalsuan atau sengketa tanah lainnya. Apabila ditemukan permohonan pemblokiran tidak melampirkan/memperlihatkan hubungan kepentingan atas tanah/pemilik tanah tersebut, maka hal ini akan berpotensi menimbulkan masalah baru. Untuk itu Kantor Pertanahan dituntut untuk lebih memperhatikan dan mencermati setiap permohonan blokir yang masuk.

Pemblokiran dilakukan sebagai langkah pengamanan berupa pencegahan/penghentian untuk sementara terhadap segala bentuk perubahan. Hal serupa juga disebutkan dalam Pasal 45 ayat (1) huruf e Peraturan Pemerintah Nomor 24 Tahun 1997 Tentang Pendaftaran Tanah bahwa Kepala Kantor Pertanahan menolak untuk melakukan pendaftaran peralihan hak atau pembebanan hak jika tanah yang bersangkutan merupakan obyek sengketa di pengadilan. Terjadinya pemblokiran hak atas tanah yang dicatatkan pada buku tanah dilaksanakan dalam rangka pemeliharaan data pendaftaran tanah. Hal ini dikarenakan adanya perubahan data yuridis yang terjadi dan harus dicatatkan pada buku tanah. Pemeliharaan data pendaftaran tanah dilakukan apabila terjadi perubahan pada data fisik atau data yuridis obyek pendaftaran tanah yang telah didaftar (Adrian Sutedi, 2010: 143).

Dengan adanya pemeliharaan data pendaftaran tanah maka data yang tersedia di Kantor Pertanahan selalu sesuai dengan keadaan yang mutakhir. Selain itu juga harus diikuti dengan kewajiban mendaftar dan pencatatan perubahan perubahan yang dimaksud pada kantor pertanahan. Pemblokiran sertipikat hak atas tanah dapat dilakukan atas dasar tanah tersebut disengketakan. Kemudian dilanjutkan dengan sita jaminan yang dimohonkan oleh pihak yang berkepentingan kepada Kantor Pertanahan untuk diblokir sampai adanya putusan pengadilan yang mempunyai kekuatan hukum tetap.

Ketentuan tersebut diatur dalam Pasal 5 Peraturan Menteri Agraria dan Tata Ruang/Kepala Badan Pertanahan Nasional Nomor 13 Tahun 2017 tentang Tata Cara Blokir dan Sita. Pada pasal tersebut dijelaskan bahwa pihak yang berkepentingan, dalam hal ini yang dimaksud dengan pihak yang berkepentingan adalah pemegang hak dan pihak atau pihak-pihak lain yang mempunyai kepentingan mengenai bidang tanah dapat minta dicatat dalam buku tanah bahwa suatu hak atas tanah akan dijadikan obyek gugatan di Pengadilan dengan menyampaikan salinan surat gugatan yang bersangkutan. Catatan tersebut hapus dengan sendirinya dalam waktu 30 hari terhitung dari tanggal pencatatan atau apabila pihak yang minta pencatatan telah mencabut permintaannya sebelum waktu tersebut berakhir. Apabila hakim yang 
memeriksa perkara tersebut memerintahkan status quo atas hak atas tanah tersebut, maka perintah tersebut dicatat dalam buku tanah. Catatan mengenai perintah ini hapus dengan sendirinya dalam waktu 30 hari, kecuali apabila diikuti dengan putusan sita jaminan yang salinan resmi dan berita acara eksekusinya disampaikan kepada Kepala Kantor Pertanahan.

Ketentuan tersebut menjelaskan bahwa terjadinya pemblokiran sertipikat hak milik atas tanah dikarenakan suatu hak atas tanah tersebut akan dijadikan obyek gugatan di pengadilan. Terjadinya pemblokiran pada Kantor Pertanahan memberikan akibat hukum terhadap hak atas tanah tersebut, yaitu tidak dapat dilakukan peralihan maupun pembebanan hak atas tanah. Segala bentuk perubahan dihentikan sementara untuk kelancaran penyelesaian sengketa. Apabila pemblokiran telah hapus dengan sendirinya atau telah dicabut, maka segala bentuk perubahan atau peralihan hak dapat dilaksanakan atau tidak dapat dicegah. Untuk mencegah terjadinya masalah baru, pemblokiran sertipikat hak milik atas tanah ini juga harus dilaksanakan sesegera mungkin agar dicatat pada buku tanah yang bersangkutan. Hal ini terkait dengan pihak ketiga, misalnya mengajukan permohonan pengecekan, peralihan hak maupun pembebanan terhadap sertipikat tersebut. Apabila telah dilakukan pencatatan pada buku tanah, maka segala bentuk perubahan tersebut tidak bisa dilakukan karena nomor hak atas tanah bersangkutan sudah diblokir.

Masa blokir tersebut berlaku selama 30 hari kalender terhitung sejak tanggal pencatatan blokir (Pasal 13 ayat 1) dan dapat diperpanjang dengan adanya perintah pengadilan berupa penetapan atau putusan (Pasal 13 ayat 2). Jadi blokir tersebut otomatis akan hilang secara hukum setelah masa 30 hari kalender terlewati. Namun permasalahannya, bagaimana jika persoalan hukum yang menyebabkan terjadinya blokir tersebut, masih dalam proses pengadilan, dipertanyakan mengenai pemberlakuan otomatis masa buka blokir sertipikat tersebut.

Pemberlakuan Peraturan Menteri Agraria dan Tata Ruang/Kepala Badan Pertanahan Nasional Nomor 13 tahun 2017 ini masih memberlakukan peraturan yang sebelumnya selama tidak bertentangan dengan peraturan menteri tersebut di atas, salah satunya yakni Peraturan Menteri Negara Agraria/Kepala Badan Pertanahan Nasional Nomor 3 Tahun 1997 tentang Petunjuk Pelaksanaan Peraturan Pemerintah Nomor 24 Tahun 1997 tentang Pendaftaran Tanah. Bahwa di Kota Bandar Lampung ada beberapa permohonan blokir dan sita yang diajukan oleh penegak hukum yakni KPK (Komisi Pemberantasan Korupsi) untuk dibekukan, hal ini dikarenakan adanya proses persidangan perkara tindak pidana korupsi diantaranya yaitu perkara yang di alami oleh Zulkifli Hasan dan Mustofa bahwa permohonan blokir dan 
sita terhadap tanah dan bangunan yang bertujuan untuk mengamankan aset para tersangka untuk dibekukan.

Berdasarkan latar belakang di atas, maka yang menjadi permasalahan yaitu bagaimana Implementasi Peraturan Menteri Agraria dan Tata Ruang/Kepala Badan Pertanahan Nasional Nomor 13 Tahun 2017 Tentang Tata Cara Blokir dan Sita pada Kantor Pertanahan Kota Bandar Lampung?, apa yang menjadi faktor penghambat Implementasi Peraturan Menteri Agraria dan Tata Ruang/Kepala Badan Pertanahan Nasional Nomor 13 Tahun 2017 Tentang Tata Cara Blokir dan Sita pada Kantor Pertanahan Kota Bandar Lampung.

\section{PEMBAHASAN}

a. Implementasi Peraturan Menteri Agraria dan Tata Ruang/Kepala Badan Pertanahan Nasional Nomor 13 Tahun 2017 Tentang Tata Cara Blokir dan Sita pada Kantor Pertanahan Kota Bandar Lampung

Berdasarkan hasil wawancara dengan Bapak Ahmad Aminullah, selaku Kepala Kantor Pertanahan Kota Bandar Lampung menyebutkan bahwa dalam hal pengaturan tentang blokir dan sita terhadap sertipikat, Kementerian Agraria dan Tata Ruang/Badan Pertanahan Nasional telah mengeluarkan Peraturan Menteri Agraria dan Tata Ruang/Kepala Badan Pertanahan Nasional Nomor 13 Tahun 2017 tentang Tata Cara Blokir dan Sita, bahwa pencatatan blokir adalah tindakan administrasi Kepala Kantor Pertanahan atau pejabat yang ditunjuk untuk menetapkan keadaan status quo (pembekuan) pada hak atas tanah yang bersifat sementara terhadap perbuatan hukum dan peristiwa hukum atas tanah tersebut, sedangkan pencatatan sita adalahtindakan administrasi Kepala Kantor Pertanahan atau pejabat yang ditunjuk untuk mencatat adanya sita dari lembaga peradilan, penyidik atau instansi yang berwenang lainnya. Pemblokiran dapat terjadi karena adanya hubungan kepentingan antara pemblokir dan pemilik tanah ataupun kepentingan pemilik tanah itu sendiri. Misalnya adanya hubungan hutang-piutang yang bermasalah, wanprestasi, sertipikat hilang, pembagian waris yang tidak adil, pemalsuan atau sengketa tanah lainnya.

Berdasarkan hasil wawancara dengan Bapak Zainal Abidin, selaku Kepala Seksi Hubungan Hukum Pertanahan bahwa berdasarkan Pasal 3 Peraturan Menteri Agraria dan Tata Ruang/Kepala Badan Pertanahan Nasional Nomor 13 Tahun 2017 tentang Tata Cara Blokir dan Sita menjelaskan bahwa Pencatatan blokir dilakukan terhadap hak atas tanah atas perbuatan hukum atau peristiwa hukum, atau karena adanya sengketa atau konflik pertanahan. Bahwa kemudian pencatatan blokir diajukan dalam rangka perlindungan hukum terhadap kepentingan atas tanah yang dimohon blokir; dan paling banyak 1 (satu) kali oleh 1 (satu) pemohon pada 1 (satu) objek tanah yang 
sama. Kemudian bahwa hak atas tanah yang buku tanahnya terdapat catatan blokir tidak dapat dilakukan kegiatan pemeliharaan data pendaftaran tanah.

Mengenai persyaratan pengajuan blokir di Kantor Pertanahan Kota Bandar Lampung saat ini telah dilaksanakan berdasarkan Peraturan Menteri Agraria dan Tata Ruang/Kepala Badan Pertanahan Nasional Nomor 13 Tahun 2017 tentang Tata Cara Blokir dan Sita yang dibagi menjadi 2 (dua) kategori yakni diantaranya pertama, pengajuan blokir oleh perorangan atau badan hukum, yaitu harus memiliki bukti hubungan hukum antara pemohon dengan tanah, seperti : (a). surat gugatan dan nomor register perkara atau skorsing oleh Pengadilan Tata Usaha Negara, dalam hal permohonan blokir yang disertai gugatan di pengadilan, (b). surat nikah/buku nikah, kartu keluarga, atau Putusan Pengadilan berkenaan dengan perceraian atau keterangan waris, dalam hal permohonan blokir tentang sengketa harta bersama dalam perkawinan dan/atau pewarisan; dan (c). putusan Pengadilan berkenaan dengan utang piutang atau akta perjanjian perikatan jual beli, akta pinjam meminjam, akta tukar menukar yang telah dilegalisir oleh pejabat yang berwenang, dalam hal permohonan blokir tentang perbuatan hukum. Berikutnya, pengajuan blokir oleh penegak hukum, yakni harus melampirkan Surat Permintaan Pemblokiran dari instansi penegak hukum disertai alasan diajukannya pemblokiran dengan memuat keterangan yang jelas mengenai : (a). nama pemegang hak; (b). jenis dan nomor hak; dan (c). luas dan letak tanah, atau syarat lainnya sesuai dengan ketentuan peraturan perundangundangan.

Setelah persyaratan-persyaratan tersebut terpenuhi dan diketahui bahwa setelah adanya permohonan blokir dari perorangan, badan hukum ataupun penyidik, pihak Kantor Pertanahan Kota Bandar Lampung dalam hal ini petugas loket melakukan pemeriksaan terhadap kelengkapan persyaratan. Apabila persyaratan permohonan telah lengkap, petugas loket menyampaikan kepada pemohon bahwa persyaratan telah lengkap dan pemohon membayar biaya sesuai dengan ketentuan peraturan perundang-undangan. Biaya yang dimaksud merupakan biaya untuk melaksanakan pengkajian dan pencatatan.Bila setelah dilaksanakan pengkajian, permohonan tidak memenuhi syarat untuk dilakukan pencatatan, maka biaya tidak dapat dikembalikan. Petugas loket menerima berkas permohonan yang telah lengkap dilampiri dengan bukti pembayaran dan kepada pemohon diberikan bukti penerimaan berkas. Bila persyaratan permohonan belum lengkap, berkas permohonan dikembalikan kepada pemohon untuk dilengkapi. Bahwa Permohonan pencatatan pemblokiran dilanjutkan dengan proses pengkajian dan pencatatan. Proses dilakukan dalam jangka waktu paling lama 3 (tiga) hari kerja sejaksurat permohonan diterima lengkap.

Pengkajian dilakukan dengan memperhatikan: 
1. Subyek/pihak yang mengajukan permohonan pencatatan blokir

2. Syarat dan alasan dapat dilakukannya pencatatan blokir

3. Jangka waktu blokir dan

4. Biaya sesuai dengan ketentuan peraturan perundang-undangan mengenai jenis dan tarif atas jenis penerimaan negara bukan pajak yang berlaku pada Kementerian Agraria dan Tata Ruang/Badan Pertanahan Nasional.

Masih menurut Bapak Zainal Abidin, selaku Kepala Seksi Hubungan Hukum Pertanahan bahwa berdasarkan Pasal 15 dan 16 Peraturan Menteri Agraria dan Tata Ruang/Kepala Badan Pertanahan Nasional Nomor 13 Tahun 2017 tentang Tata Cara Blokir dan Sita bahwa catatan blokir hapus apabila:

1. Catatan blokir oleh perorangan atau badan hukum, hapus apabila jangka waktu blokir berakhir dan tidak diperpanjang, pihak yang memohon pencatatan telah mencabut permintaannya sebelum jangka waktu berakhir, Kepala Kantor menghapus blokir sebelum jangka waktunya berakhir; atau ada perintah pengadilan berupa putusan atau penetapan.

2. Catatan blokir oleh penegak hukum, hapus apabila: kasus pidana yang sedang dalam penyidikan dan penuntutan telah dihentikan; atau penyidik mengajukan penghapusan catatan blokir.

Untuk biaya yang harus di keluarkan dalam permohonan blokir berdasarkan Lampiran Peraturan Pemerintah Nomor 128 Tahun 2015 tentang Jenis dan Tarif atas jenis Penerimaan Negara Bukan Pajak yang berlaku pada Kementerian Agraria dan Tata Ruang/Badan Pertanahan Nasional, biayanya sebesar Rp. 50.000,- (lima puluh ribu rupiah) per bidang yang diajukan untuk dilakukan pemblokiran.

Selanjutnya menurut A.Negra Mardenitami, selaku Kepala Sub Seksi Penanganan Sengketa, Konflik dan Perkara Pertanahan, struktural yang berhubungan langsung dengan blokir dan sita, menyebutkan bahwa dalam hal pelaksanaan pemblokiran suatu sertipikat permohonan pencatatan blokir dapat diajukan oleh perorangan, badan hukum atau penegak hukum. Kemudian bahwa permohonan pencatatan blokir harus mencantumkan alasan yang jelas dan bersedia dilakukan pemeriksaan atas permohonan dimaksud. Permohonan perorangan atau badan hukum wajib mempunyai hubungan hukum dengan tanah yang dimohonkan pemblokiran.adapun pemohon yang mempunyai hubungan hukum terdiri dari:

1. Pemilik tanah, baik perorangan maupun badan hukum

2. Para pihak dalam perjanjian baik notariil maupun di bawah tangan atau kepemilikan harta bersama bukan dalam perkawinan;

3. Ahli waris atau kepemilikan harta bersama dalam perkawinan;

4. Pembuat perjanjian baik notariil maupun di bawah tangan, berdasarkan kuasa; ataubank, dalam hal dimuat dalam akta notariil 
para pihak.

5. Penegak hukum dapat mengajukan pencatatan blokir untuk penyidikan dan penuntutan kasus pidana.

Penjelasan dari A.Negra Mardenitami, selaku Kepala Sub Seksi Penanganan Sengketa, Konflik dan Perkara Pertanahan bahwa menurut peraturan perundang-undangan yang baru mengenai blokir yakni Peraturan Menteri Agraria dan Tata Ruang/Kepala Badan Pertanahan Nasional Nomor 13 Tahun 2017 tentang Tata Cara Blokir dan Sita bahwa catatan blokir di Kantor Pertanahan Kota Bandar Lampung memiliki jangka waktu diantaranya catatan blokir oleh perorangan atau badan hukum berlaku untuk jangka waktu 30 (tiga puluh) hari kalender terhitung sejak tanggal pencatatan blokir. Jangka waktu tersebutdapat diperpanjang dengan adanya perintah pengadilan berupa penetapan atau putusan. Kemudian catatan blokir oleh penegak hukum berlaku sampai dengan dihentikannya kasus pidana yang sedang dalam penyidikan dan penuntutan, atau sampai dengan dihapusnya pemblokiran oleh penyidik yang bersangkutan. Kepala Kantor Pertanahan dapat meminta keterangan kepada penyidik terkait kasus atas tanah yang dicatat blokir. Namun terkadang, masa blokir ini sering menjadi permasalahan, terutama permohonan blokir dari perorangan, yang beranggapan bahwa blokir yang mereka ajukan tidak perlu diajukan perpanjangan, meskipun masa blokirnya sudah habis. Kendala lain, ketika masa blokir habis 30 hari, tidak serta merta langsung otomatis blokir terbuka, tetap saja para pemohon, baik itu perorangan, badan hukum atau penegak hukum, harus mengajukan aktifitas cabut atau buka blokir.

Selanjutnya bahwa terkait pelaksanaan pencatatan sita oleh Kantor Pertanahan Kota Bandar Lampung menurut A.Negra Mardenitami, selaku Kepala Sub Seksi Penanganan Sengketa, Konflik dan Perkara Pertanahan bahwa pencatatan Sita dilakukan terhadap hak atas tanah dalam rangka kepentingan penyelesaian perkara di pengadilan atau penyidikan. Bahwa pencatatan Sita tersebut diajukan paling banyak 1 (satu) kali oleh 1 (satu) pemohon pada 1 (satu) objek tanah yang sama. Selanjutnya bahwa hak atas tanah yang berada dalam keadaan disita tidak dapat dialihkan dan/atau dibebani hak tanggungan. Hak atas tanah yang berada dalam keadaan disita dapat di roya, diperpanjang dan/atau diperbaharui dengan memberitahukan kepada Ketua Pengadilan, para pihak yang berperkara dan/atau penyidik.

Bahwa pencatatan sita di Kantor Pertanahan sesuai Pasal 26 Peraturan Menteri Agraria dan Tata Ruang/Kepala Badan Pertanahan Nasional Nomor 13 Tahun 2017 tentang Tata Cara Blokir dan Sita bahwa pencatatan sita terdiri dari pencatatan sita perkara dilakukan terhadap hak atas tanah yang sedang menjadi obyek perkara di pengadilan, pencatatan Sita Pidana dilakukan dalam rangka penyidikan dan pencatatan Sita Berdasarkan Surat Paksa yakni 
pencatatan sita terhadap hak atas tanah yang menjadi obyek utang pajak sesuai dengan ketentuan peraturan perundang-undangan.

Menurut A.Negra Mardenitami, selaku Kepala Sub Seksi Penanganan Sengketa, Konflik Dan Perkara Pertanahan bahwa ketiga jenis pencatatan sita tersebut dapat di ajukan oleh :

1. Permohonan pencatatan Sita Perkara, diajukan oleh juru sita pengadilan; atau pihak yang berkepentingan meliputi penggugat atau tergugat, untuk kepentingan penyelesaian perkara di pengadilan. dengan melampirkan: penetapan sita dari Ketua Pengadilan yang menerangkan secara jelas mengenai subyek hak, jenis hak, nomor hak dan letak tanah yang diletakkan sita; dan/atau putusan pengadilan yang menyatakan sah dan berharga sita terhadap hak atas tanah obyek perkara.

2. Permohonan pencatatan Sita Pidana diajukan oleh penyidik/penegak hukum dilengkapi dengan melampirkan: Surat Izin Ketua Pengadilan Negeri setempat, sesuai dengan tempat terjadinya tindak pidana; surat perintah penyitaan yang ditandatangani oleh penyidik; penetapan pengadilan; dan/atau syarat lainnya sesuai dengan ketentuan peraturan perundang- undangan.

3. Pencatatan Sita Berdasarkan Surat Paksa diajukan oleh juru sita pajak dilengkapi dengan melampirkan Surat Perintah melaksanakan Penyitaan dari instansi yang berwenang. Bahwa biaya yang harus dikeluarkan oleh pemohon sita berdasarkan Lampiran Peraturan Pemerintah Nomor 128 Tahun 2015 tentang Jenis dan Tarif atas jenis Penerimaan Negara Bukan Pajak yang berlaku pada Kementrian Agraria dan Tata Ruang/BPN, biaya nya sebesar Rp. 50.000,- (lima puluh ribu rupiah) per bidang yang diajukan untuk dilakukan sita. Terkhusus untuk biaya Penerimaaan Negara Bukan Pajak Pelayanan Sita ini, sering ditemukan permohonan dari Penegak Hukum hanya melampirkan Surat Permohonan Pengangkatan Sita, tanpa melakukan akifitas pembayaran biaya PNBP tersebut.

Bapak Zainal Abidin, selaku Kepala Seksi Hubungan Hukum Pertanahan adapun dampak adanya pencatatan blokir dan sita adalah untuk perlindungan hukum terhadap kepentingan atas tanah yang dimohon blokir, kemudian bahwa hak atas tanah yang buku tanahnya terdapat catatan blokir tidak dapat dilakukan kegiatan pemeliharaan data pendaftaran tanah bahwa dalam hal ini tanah tersebut tidak dapat dialihkan ke orang lain sebelum pencatatan blokir dan sita tersebut hapus oleh si pemohon tersebut.

Berdasarkan pemaparan oleh Bapak Zainal Abidin, selaku Kepala Seksi 
Hubungan Hukum Pertanahan dan A.Negra Mardenitami, selaku Kepala Sub Seksi Penanganan Sengketa, Konflik Dan Perkara Pertanahan bahwa implementasi Peraturan Menteri Agraria dan Tata Ruang/Kepala Badan Pertanahan Nasional Nomor 13 Tahun 2017 Tentang Tata Cara Blokir dan Sita pada Kantor Pertanahan Kota Bandar Lampung dilaksanakan sesuai dengan amanat peraturan tersebut, baik dari prosedur pengajuan permohonan meliputi persyaratan, melakukan tindakan pengkajian dengan memperhatikan aturan yang ada, melakukan pencatatan dengan lengkap, serta penerapan jangka waktu blokir dan sita yang telah disesuaikan dengan peraturan tersebut yakni terhadap blokir yakni 30 (tiga puluh) hari sejak tanggal pencatatan blokir apabila tidak diperpanjang kemudian untuk sita berlaku sampai dengan adanya putusan pengadilan yang telah berkekuatan hukum tetap yang salah satu amarnya menyatakan gugatan ditolak atau tidak dapat diterima atau mengenai pengangkatan sita maupun penetapan penghapusan/pengangkatan sita.Namun masih terkendala mengenai masa blokir dan pembayaran biaya Penerimaan Negara Bukan Pajak (PNBP).

Menurut Teori yang dikemukakan oleh Roscoe Pound yang menjelaskan bahwa kontrol sosial diperlukan untuk menguatkan peradaban masyarakat manusia karena mengendalikan perilaku antisosial yang bertentangan dengan kaidah-kaidah ketertiban sosial. Hukum, sebagai mekanisme kontrol sosial, merupakan fungsi utama dari negara dan bekerja melalui penerapan kekuatan yang dilaksanakan secara sistematis dan teratur oleh agen yang ditunjuk untuk melakukan fungsi itu. Akan tetapi, Pound menambahkan bahwa hukum saja tidak cukup, ia membutuhkan dukungan dari institusi keluarga, pendidikan, moral, dan agama. Hukum adalah sistem ajaran dengan unsur ideal dan empiris, yang menggabungkan teori hukum kodrat dan positivistik. Dalam teori Law as a tool of sosial engineering yang dikemukakan oleh Roscoe Pound sebagaimana yang dikemukakan juga oleh Mochtar Kusumaatmaja dengan teori pembaharuan atau pembangunan hukum menjelaskan bahwa hukum sebagai alat pembaharuan dalam masyarakat, dalam istilah ini hukum diharapkan dapat berperan merubah nilai-nilai sosial dalam masyarakat.

Law as a tool of social engineering dapat pula diartikan sebagai sarana yang ditujukan untuk mengubah perilaku warga masyarakat, sesuai dengan tujuan-tujuan yang telah ditetapkan sebelumnya. Berdasarkan hal tersebut di atas maka dapat di analisis yaitu berdasarkan teori yang dikemukakan oleh Roscoe Pound yang di kembangkan oleh Mochtar Kusumaatmaja bahwa hukum di bentuk sebagai alat pembaharuan dalam masyarakat, dalam istilah ini hukum diharapkan dapat berperan merubah nilai-nilai sosial dalam masyarakat. Dalam hal ini dengan adanya fungsi hukum sebagai sarana pembaharuan masyarakat, hal ini dapat diketahui dengan adanya pembaharuan hukum mengenai prosedur tata cara blokir dan sita di Kantor 
Pertanahan yakni melalui Peraturan Menteri Agraria dan Tata Ruang/Kepala Badan Pertanahan Nasional Nomor 13 Tahun 2017 tentang Tata Cara Blokir dan Sita.

Bahwa berdasarkan teori tersebut maka implementasi Peraturan Menteri Agraria dan Tata Ruang/Kepala Badan Pertanahan Nasional Nomor 13 Tahun 2017 Tentang Tata Cara Blokir dan Sita pada Kantor Pertanahan Kota Bandar Lampung saat ini belum dilaksanakan secara maksimal sesuai dengan amanat peraturan tersebut dikarenakan pemohon perorangan/badan hukum atau penegak hukum kurang memahami mengenai masa blokir yang hanya berjangka 30 hari. Masa blokir yang habis, tidak serta merta otomatis blokir terbuka, perlu tetap dilakukan aktifitas cabut blokir, yang mana pengajuannya harus melampirkan persyaratan administratif, kemudian untuk sita, para penegak hukum kurang memahami biaya Penerimaan Negara Bukan Pajak yang harus dikeluarkan dalam pengajuan permohonan sita.

\section{b. Faktor penghambat Implementasi Peraturan Menteri Agraria dan Tata Ruang/Kepala Badan Pertanahan Nasional Nomor 13 Tahun 2017 Tentang Tata Cara Blokir dan Sita pada Kantor Pertanahan Kota Bandar Lampung}

Menurut A.Negra Mardenitami, S.H. selaku Kepala Sub Seksi Penanganan Sengketa, Konflik dan Perkara Pertanahanbahwa dalam penerapan Peraturan Menteri Agraria dan Tata Ruang/Kepala Badan Pertanahan Nasional Nomor 13 Tahun 2017 Tentang Tata Cara Blokir dan Sita pada Kantor Pertanahan Kota Bandar Lampungtelah dilakukan upaya atau usaha-usaha agar dalam pelaksanaannya dapat berjalan lancar sesuai dengan yang diharapkan, namun dalam pelaksanaannya masih dijumpai adanya beberapa hambatan yang dihadapi oleh Kantor Pertanahan Kota Bandar Lampung baik dari segi teknis maupun non teknis.

Bahwa menurut teori yang dikemukakan oleh Lawrence Meir Friedman yang menegaskan bahwa hukum itu sebagai usaha pencapaian tujuan tertentu dalam hal ini hukum berperan sebagai guide, patokan pedoman dalam pelaksanaan program pemerintah dengan kata lain hukum dijadikan alat pelaksanaan keputusan, program poltik, dan hukum pun dikondisikan untuk memperlancar, bahkan mengamankan pelaksanaan pembangunan. Kesadaran hukum menurut teori Friedman terkait erat dengan budaya hukum masyarakatnya dengan kata lain dapat dijelaskan bahwa tingkat kesadaran hukum masyrakat tinggi atau rendah dapat dilihat pada budaya hukumnya, jika budaya hukumnya cenderung posisitf, proaktif terhadaap cita hukum tentu masyarakatnya memilki kesadaran hukum yang tinggi.

Dalam hal ini fungsi hukum mengalami perluasan yang mulanya 
sebagai kontrol sosial dan pemertahanan pola sosial bergeser ke arah perubahan tingkah laku yang dikehendaki hukum.

Jika demikian dapat digeneralisasikan bahwa tingkah laku masyarakat Negara dapat dilihat pada hukumnya, yaitu jika hukumnya bertujuan mengontrol dan mempertahankan pola hidup warga Negara tetap dan mapan dalam bertingkah laku.

Menurut teori Lawrence Meir Friedman bahwa apabila berbicara mengenai penegakan hukum, maka itu berarti harus membahas sistem hukum, bahwa berhasil atau tidaknya penerapan hukum tergantung dari sistem hukum tersebut berjalan. Oleh karena itu faktor penghambat implementasi Peraturan Menteri Agraria dan Tata Ruang/Kepala Badan Pertanahan Nasional Nomor 13 Tahun 2017 Tentang Tata Cara Blokir dan Sita pada Kantor Pertanahan Kota Bandar Lampung jika di analisis berdasarkan teoriSistem Hukum yang menyatakan ada tiga unsur yang terkait dalam penerapan suatu peraturan yaitu:

1. Legal Substance (Substansi Hukum) Merupakan aturan-aturan, normanorma, dan pola prilaku nyata manusia yang berada dalam sistem itu termasuk produk yang dihasilkan oleh orang yang berada didalam sistem hukum itu mencakup keputusan yang mereka keluarkan atau aturan baru yang mereka susun. Adapun faktor penghambat di ukur dari substansi hukum diantaranya yaitu masih belum singkronnya antara peraturan menteri tentang tata cara blokir dan sita dengan aplikasi pelayanan pertanahan (KKP), bahwa menurut Peraturan Menteri dan Tata Ruang/Kepala Badan Pertanahan Nasional Nomor 13 Tahun 2017 menyebutkan bahwa habisnya blokir yakni 30 hari sedangkan dalam aplikasi tidak terbuka secara otomatis harus ada aktivitas buka blokir, belum adanya aturan khusus/penyesuaian mengenai blokir khususnya dalam aplikasi pelayanan pertanahan (KKP) sehingga masih menggunakan Permen ATR nomor 5 Tahun 2017 tentang Layanan Informasi Pertanahan Secara Elektronik.

2. Legal Structure (Struktur hukum) Melingkupi pranata hukum, aparatur hukum dan sistem penegakkan hukum. Faktor penghambat diantaranya yaitu masihkurangnya informasi penegak hukum mengenai biaya PNBP dalam permohonan blokir bahwa sebagian penegak hukum yang belum paham mengenai prosedur permohonan blokir yang dimana penegak hukum khususnya penyidik hanya bersurat meminta blokir tanpa disertai biaya PNBP sehingga pelayanannya menjadi terhambat, bisa terindikasi kerugian Negara jika pencatatan blokir tanap melewati prosedur pelayanan di loket pembayaran, dan kurangnya sosialisasi mengenai prosedur dan tata cara permohonan blokir sehingga pemahaman pemohon tentang 
jangka waktu blokir kurang mendalam.

3. Legal culture (Budaya hukum)

Merupakan penekanan dari sisi budaya secara umum, kebisaaan-

kebisaaan, opini- opini, cara bertindak dan berpikir, yang mengarahkan kekuatan sosial dalam masyarakat. Bahwa faktor penghambat yang dilihat dari budaya hukumnya diantaranya yaitu kurangnya pengetahuan masyarakat mengenai prosedur permohonan serta jangka waktu blokir, masih ditemukannya persyaratan dari pemohon yang kurang lengkap yang dimana tidak ada keterangan subyek dan obyek blokir, alamat pemohon blokir dan sita yang tidak sama dengan KTP sehingga korespondensi surat menyurat menjadi tidak lancar, surat pernyataan mengenai ketersediaan buka blokir jika sudah 30 hari terkadang tidak ditanda tangani oleh pemohon

\section{PENUTUP}

Berdasarkan hasil pembahasan dan penelitian terhadap permasalahan maka dapat disimpulkan bahwa implementasi Peraturan Menteri Agraria dan Tata Ruang/Kepala Badan Pertanahan Nasional Nomor 13 Tahun 2017 Tentang Tata Cara Blokir dan Sita pada Kantor Pertanahan Kota Bandar Lampung saat ini belum dilaksanakan secara maksimal sesuai dengan amanat peraturan tersebut dikarenakan pemohon perorangan/badan hukum atau penegak hukum kurang memahami mengenai masa blokir yang hanya berjangka 30 hari. Masa blokir yang habis, tidak serta merta otomatis blokir terbuka, perlu tetap dilakukan aktifitas cabut blokir, yang mana pengajuannya harus melampirkan persyaratan administratif, kemudian untuk sita, para penegak hukum kurang memahami biaya Penerimaan Negara Bukan Pajak yang harus dikeluarkan dalam pengajuan permohonan sita.

Faktor penghambat implementasi Peraturan Menteri Agraria dan Tata Ruang/Kepala Badan Pertanahan Nasional Nomor 13 Tahun 2017 Tentang Tata Cara Blokir dan Sita pada Kantor Pertanahan Kota Bandar Lampung diantaranya yaitu masih belum sinkronnya antara Peraturan Menteri Agraria dan Tata Ruang/Kepala Badan Pertanahan Nasional Nomor 13 Tahun 2017 Tentang Tata Cara Blokir dan Sita dengan aplikasi pelayanan pertanahan (KKP), yaitu mengenai masa/jangka waktu blokir; belum adanya aturan khusus/penyesuaian mengenai blokir khususnya dalam aplikasi pelayanan pertanahan (KKP) sehingga masih menggunakan Peraturan Menteri Agraria dan Tata Ruang/Kepala Badan Pertanahan Nasional Nomor 5 Tahun 2017 tentang Layanan Informasi Pertanahan Secara Elektronik; Masih kurangnya informasi penegak hukum tentang jangka waktu blokir, terkait permohonan sita, penegak hukum masih kurang informasi mengenai biaya PNBP yang harus 
dikeluarkan apabila mencabut sita., serta kurangnya pengetahuan masyarakat mengenai prosedur permohonan serta jangka waktu blokir; hubungan subjek dan objek blokir yang tidak jelas; serta ketidaklancaran korespondensi surat menyurat kepada pemohon perorangan atau badan hukum.

Bagi pemerintah pusat, khususnya Kementerian Agraria dan Tata Ruang/BPN, dalam hal ini kementerian yang mengeluarkan peraturan, hendaknya agar dapat mensingkronkan peraturan-peraturan yang ada khususnya mengenai blokir dengan Aplikasi KKP, sehingga dalam pelaksanaannya dapat berjalan dengan lancar dan efektif, dan tidak menimbulkan ketidakteraturan dan bagi Kantor Pertanahan Kota Bandar Lampung hendaknya agar lebih meningkatkan sosialisasi dan edukasi kepada masyarakat, termasuk Aparat Penegak Hukum mengenai prosedur, tata cara serta jangka waktu permohonan blokir sesuai Peraturan Menteri Agraria dan Tata Ruang/Kepala Badan Pertanahan Nasional Nomor 13 Tahun 2017 Tentang Tata Cara Blokir dan Sita dan biaya Penerimaan Negara Bukan Pajaknya sehingga kendala maupun hambatan dalam pelaksanaannya dapat diminimalisir.

\section{DAFTAR PUSTAKA}

\section{A. Buku}

Adrian Sutedi. 2012. Sertifikat Hak Atas Tanah. Sinar Gafika. Jakarta

Aartje Tehupeiory. 2012. Pentingnya Pendaftaran Tanah di Indonesia. Raih Asa Sukses. Jakarta

Achmad Sodikin. 1997. Pembaharuan Hukum Pertanahan Nasional Dalam Rangka Penguatan Agenda Landreform. Arena Hukum. Jakarta.

Aminuddin Sale dkk. 2010. Hukum Agraria. AS Publising. Yogyakarta

A.P Parlindungan. 1978. Pedoman Pelaksanaan UUPA dan Tata Cara Pejabat Pembuat Akta Tanah. Alumni. Bandung

Boedi Harsono. 2005. Hukum Agraria Indonesia. Sejarah Pembentukan UndangUndang Pokok Agraria. Isi dan Pelaksanaanya. Djambatan. Jakarta

Bryan A. Gadner. 2004. Black's Law Dictionary: Eighth Edition. USA: West Publishing Co

B.F. Sihombing. 2005. Evolusi Kebijakan Pertanahan Dalam Hukum Tanah Indonesia. Gunung Agung. Jakarta

Kartini Muljadi dan Gunawan W. 2004. Hak-Hak Atas Tanah Seri Hukum Harta Kekayaan. Prenada Media. Jakarta

Lawrence. M. Friedman. Teori dan Filsafat Hukum: telaah kritis atas Teori -Teroi Hukum. cetakan kedua. Raja Grafindo Persada. Jakarta. 1993

M. Yahya Harahap. 2005. Hukum Acara Perdata. Sinar Grafika. Jakarta 
Philipus M. Hadjon. dkk. 1994. Pengantar Hukum Indonesia. Gadjah Mada University Press Yogyakarta

Purnadi P. dan A. Ridwan H. 1984. Sendi-Sendi Hukum Agraria. Ghalia Indonesia. Jakarta

R. Soeroso. 1992. Pengantar Ilmu Hukum. Sinar Grafika. Jakarta

Soehino. 1984. Asas-Asas Hukum Tata Pemerintahan. Liberty. Yogyakarta

Soerjono Soekanto dan Sri Mamudji. 1995. Penelitian Hukum Normatif Suatu Tinjauan Singkat. Rajawali Press.Jakarta

S. Prajudi Atmosudirjo. 1981. Hukum Administrasi Negara. Ghalia Indonesia. Jakarta Urip Santoso. 2010. Pendaftaran dan Peralihan Hak Atas Tanah. Kencana. Jakarta ----------. 2009. Hukum Agraria dan hak-hak Atas Tanah. Jakarta: Kencana

William N. Dunn. Pengantar Analisis Kebijakan Publik (Edisi Kedua). Gadjah Mada University Press. Yogyakarta. 2003

\section{B. Peraturan Perundang-undangan}

Undang-Undang Dasar Negara Republik Indonesia Tahun 1945

Ketetapan Majelis Permusyawaratan Rakyat tentang Pembaharuan Agraria dan Pengelolaan Sumber Daya Alam. No. IX Tahun 2001;

Undang-Undang Nomor 5 Tahun 1960 tentang Pokok-Pokok Agraria;

Undang-Undang Nomor 20 Tahun 1961 tentang Pencabutan Hak-hak Tanah dan Benda-benda yang Ada di atasnya;

Undang-Undang Nomor 39 Tahun 1999 tentang Hak Asasi Manusia;

Peraturan Pemerintah Nomor 8 Tahun 1953 tentang Penguasaan Tanah-tanah Negara;

Peraturan Pemerintah Nomor 28 Tahun 1977 tentang Perwakafan Tanah Milik;

Peraturan Pemerintah Nomor 40 Tahun 1996 tenang Hak Guna Usaha. Hak Guna Bangunan. dan Hak Pakai.

Peraturan Pemerintah Nomor 24 Tahun 1997 tentang Pendaftaran Tanah;

Instruksi Presiden Nomor 9 Tahun 1973 tentang Pelaksanaan Pencabutan Hak hak Tanah dan Benda-benda yang ada diatasnya;

Keputusan Presiden Nomor 55 Tahun 1993 tentang Pengadaan Tanah Bagi Pelaksanaan Pembangunan untuk Kepentingan Umum;

Keputusan Presiden Nomor Nomor 34 Tahun 2003 tentang Kebijakan Nasional di Bidang Pertanahan;

Peraturan Presiden Nomor 36 Tahun 2005 tentang Pengadaan Tanah bagi Pelaksanaan Pembangunan untuk Kepentingan Umum;

Peraturan Presiden Nomor 65 Tahun 2006 tentang Perubahan atas Peraturan Presiden Nomor 36 Tahun 2005 tentang Pengadaan Tanah Bagi Pelaksanaan Pembangunan Untuk Kepentingan Umum. 
Peraturan Menteri Dalam Negeri Nomor 5 Tahun 1974 tentang Ketentuanketentuan Mengenai Penyediaan dan Pemberian Hak Untuk Keperluan Perusahaan;

Peraturan Menteri Dalam Negeri Nomor 15 Tahun 1975 tentang Ketentuanketentuan mengenai Tata Cara Pembebasan Tanah;

Peraturan Menteri Negara Agraria/Kepala Badan Pertanahan Nasional Nomor 1 Tahun 1994 tentang Pelaksanaan Pengadaan Tanah;

Peraturan Menteri Agraria/ Kepala Badan Pertanahan Nasional Nomor 3 Tahun 1997 tentang Ketentuan Pelaksanaan dari Peraturan Pemerintah Nomor 24 Tahun 1997 tentang Pendaftaran Tanah;

Peraturan Menteri Negara Agraria/ Kepala Badan Pertanahan Nasional Nomor 9 Tahun 1999 tentang Tata Cara Pemberian dan Pembatalan Hak Atas Tanah dan Hak Pengelolaan;

Peraturan Menteri Agraria dan Tata Ruang/Kepala Badan Pertanahan Nasional Nomor 13 Tahun 2017 Tentang Tata Cara Blokir dan Sita. 


\section{PEDOMAN PENULISAN JURNAL PRANATA HUKUM}

1. Naskah bersifat orisinil, baik berupa hasil riset atau tinjauan atas suatu permasalahan hukum yang berkembang di masyarakat (artikel lepas), dimungkinkan juga tulisan lain yang dipandang memberikan kontribusi bagi pengembangan ilmu hukum.

2. Penulisan terdiri atas beberapa bab penulisan hasil penelitian terdiri dari 3BAB,yaitu ;

BAB I. PENDAHULUAN (Latar Belakang dan Rumusan Masalah) BAB II. PEMBAHASAN (Kerangka Teori dan Analisis), dan BAB III. PENUTUP (Kesimpulan dan Saran).

3. Tulisan menggunakan bahasa indonesia maupun bahasa inggris yang memenuhi kaidah bahasa yang baik dan benar,tulisan menggunakan bahasa indonesia disertai abstrak dalam bahasa inggris (200 kata) dan Kata kunci, ketentuan ini berlaku sebaliknya.

4. Setiap kutipan harus menyebutkan sumbernya, dan ditulis pada akhir kutipan dengan memberi tanda kurung (bodynote). Sumber kutipan harus memuat nama pengaran, tahun penerbitan dan halaman .Contoh : satu penulis (Bagir Manan, 1994: 20), Dua Penulis (Jimly Asshidiqqie dan M.Ali Syafa'at, 2005: 11), Tiga atau lebih penulis menggunakan ketentuan et.al (dkk). Untuk artikel dari internet dengan susunan: nama penulis, judul tulisan digaris bawah, alamat website, waktu download/unduh.

5. Naskah harus disertai dengan daftar pustaka atau referensi ,terutama yang digunakan sebagai bahan acuan langsung. Daftar pustaka dan referensi bersifat alfabetis dengan format; nama pengarang, judul buku, nama penerbit, kota terbit, dan tahun penerbitan. Contoh: Bagir Manan, Hubungan Antara Pemerintah Pusat dan Daerah Menurut UUD 1945, Pustaka Sinar Harapan, Jakarta, 1994.

6. Panjang tulisan antara 15-25 halaman, font times new roman dengan 1,15 spasi. Dalam hal hal tertentu berlaku pengecualian panjang tulisan.

7. Naskah disertai nama lengkap penulis, alamat e-mail dan lembaga tempat berafiliasi saat ini, dan hal lain yang dianggap penting. 


\section{Jurnal PRANATA HUKUM dimaksudkan sebagai}

media komunikasi, edukasi, dan informasi ilmiah bidang ilmu hukum khususnya, dan ilmu sosial pada umumnya. Sajian dan kemasan diupayakan komunikatif melalui bahasa ilmiah.

Redaksi mengundang semua elemen masyarakat baik civitas akademika, praktisi, lembaga masyarakat, maupun perorangan yang berminat terhadap bidang hukum untuk berpartisipasi mengembangkan gagasan, wawasan, dan pengetahuan melalui tulisan untuk dimuat dalam jurnal ini.

Melalui PRANATA HUKUM diharapkan terjadi proses pembangunan dan pengembangan bidang hukum sebagai bagian penting dari rangkaian panjang proses memajukan masyarakat bangsa.

Alamat Redaksi

PRANATA HUKUM

Kampus B Universitas Bandar Lampung Jl. ZA Pagar Alam No.89 Labuhan Ratu, Bandar

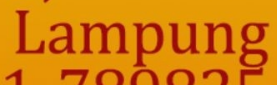

Telp: 0721-789825

Email: jurnal.mh@ubl.ac.id

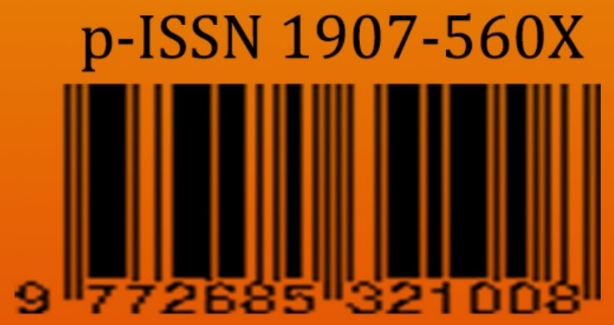

